\title{
The Brazilian Journal of Geology migrates to the ScholarOne editorial system
}

The Brazilian Journal of Geology (BJG) is just starting to migrate from the Open Journal Systems (OJS) to the ScholarOne editorial system, as part of the Scientific Electronic Library Online (SciELO). The new system will be offered for submission of papers in the sites of the Sociedade Brasileira de Geologia (SBG) and the SciELO from July 1', 2015.

The ScholarOne is the editorial system used by most of the principal scientific journals. It is supposed to be friendly for authors, editors and reviewers, and shall make easier the entire editorial process, causing an important reduction of the evaluation process and the preparation for publication. This migration will bring great benefits for the professionalization of the journal and also for its internationalization.

Instructions to authors will be reviewed in the site of the Brazilian Geological Society. Moreover, the secretariat of the BJG will continue to operate with the OJS system until the termination of the evaluation processes in course.

\section{Umberto G. Cordani ${ }^{1}$} Claudio Riccomini ${ }^{1}$ 